\title{
ANALYSIS THE TYPE OF DEIXIS IN THE MAIN CHARACTER ON THE MOVIE I LEAVE MY HEART IN LEBANON
}

\author{
Evi Viahapsari' ${ }^{1}$, Aseptiana Parmawati \\ ${ }^{1}$ IKIP Siliwangi \\ ${ }^{2}$ IKIP Siliwangi \\ ${ }^{1}$ eviviahapsari1@gmail.com, ${ }^{2}$ aseptianaparmawati@gmail.com
}

\begin{abstract}
This study aimed to describe the type of deixis on the main character in the film titled I Leave My Heart in Lebanon. This research is descriptive qualitative research.The data of this research was collected by analysis of the use of language spoken by the main character in the film I Leave My Heart in Lebanon, with the stages: 1) Organizing the data by collects of all the data in the movie that contains of deixis. 2) Categorizing the data into the types based on levinson theory who classified deixis into deixis persona, spatial, temporal, discourse, and social. 3) Analyzing the data which containing five types of deixis. 4) Present the sample of the data that related to the study, the researcher will present the result of the research some of each category. All of the sources taken on the Film I Leave My Heart in Lebanon. Based on data analysis, the researcher found 125 data that indicates the type of deixis. including personal, temporal, spatial, social, and discourse deixis. The deixis in this film are dominated by personal deixis with 102 data.
\end{abstract}

Keywords: Analysis, Deixis, Movie

\section{INTRODUCTION}

As human social beings who need each other, communication is an activity that cannot be avoided. With communication, peoples are easy to share the ideas, extend the information, express what people are feel and so on. This explanation as mentioned by Hybel \& Weaver (2004) in Indah et.al (2018) who defined communication as an interaction process between one person to another which aimed to the information and beliefs, swap ideas, making plan and solve the problem. The explanation shows that communication is very use full and have important role for human in order to carry the message, exchange ideas, express what people are fell, and also for sharing the information to others.

In doing communication, people usually pointing something via language, that phenomenon known as Deixis. According to Levinson (1983) in Ainiyah et.al (2019) deixis is a word which its reference always moves or changes depending on the context to indicate person, place, time, social distinction, and role in discourse. Phenomenon of deixis not only happen on the daily conversation, but also happen in the conversation on the main character in the movie. One of the movie which contain of deixis is the film titled I Leave My Heart in Lebanon. I Leave My Heart in Lebanon produce by TB Silalahi production. This movie which released on December 15, 2016 tells about the story of the garuda troops who maintain peace in Lebanon, this film 
nuanced action and romans directed by Beni Setiawan and Written by TB silalahi and also Zairin Zain. The main character of this movie is who role by Rio Dewanto.

In the film I Leave My Heart in Lebanon, the actor named Satria always using deixis. The deixis that used by actor named satria is person deixis, temporal deixis, spatial deixis, social deixis and discourse deixis. All of the deixis that used by satria is related with the type of deixis based on the theory of Levinson (1983) in Ainiyah (2019) who classified deixis into five types, that is personal, spatial, temporal, social and discourse deixis. By consider the explanation above, the researcher interested to analyze the kind of deixis in the main character on the film titled I Leave My Heart in Lebanon The objective of this research is to analyze and find the kind of deixis on the main character in the film I Leave My Heart in Lebanon

\section{a. Person Deixis}

According to Levinson, person deixis concern on point the person via pronoun, as first personal deixis (refers to speaker himself), second personal deixis (refers to one or more addresses), and third person (refers to other than speaker or opponent he said). That explanation as define by Nadar F.X (2009) who define deixis as the use of the first person pronoun to referrer for himself, the second person to point one direction or more opponents he said, while the third person to designate other than the speaker or opponent. In other word, person deixis apply to replace the name or thing by using pronoun.

b. Spatial Deixis

Levinson (1983) in Abidin (2019) mentioned that spatial deixis concern to encoding of spatial location relative to the location of the participants in the speech. Yule (1996:12) in Pangaribuan et.al (2014) states that in considering spatial deixis, however, it is important to remember that location from the speaker's perspective can be fixed mentally as well as physically. Spatial deixis or place deixis used to display the site related to the location of participant in speech event. For instance "Here", "There", "Where".

c. Temporal deixis

Levinson stated that temporal deixis is important to differentiate the moment of utterance from the moment of reception. Mayer (2009:187) in Syukur (2018) stated that temporal deixis is stamped linguistically by both temporal adverbials such as yesterday, tomorrow, in the morning, and tense markers like present and past on verbs

d. Social Deixis

Social deixis is a type of deixis used by speakers to show a person's characteristics or differences in social characteristics between speaker and interlocutor or writer and reader with the topic or reference referred to in the conversation. According to levinson (1983) in Ainiyyah et.al (2019) social deixis refers to those aspects of language structure that state the social identities of participant, or social relationship between interlocutors, or between one of them and persons and entities referred to.

e. Discourse Deixis

The last among the types of deixis propounded by Levinson is discourse deixis. Discourse deixis is deictic reference toward a discourse related to the speaker's current "location" in the discourse. levinson (1983) in Abdullah (2015) argue that discourse deixis entails the possibility of anaphoric references which provides a reference to an utterance backward or forward to other utterances. Such as the use of word "This" and "That". For example: "I hate this moment". 


\section{METHOD}

In doing the research, this study was used descriptive qualitative method with content analysis as its approach. Qualitative research is a research method that explain in detail by describing the data obtained. That definition as stated by Bogdan \& Biklen, S. (1992:21-22) in Putri \& Mulyana (2019) who defined qualitative method as one of the research procedures that obtain descriptive data in the form of speech or writing and observed behavior. The data of this research was collected by analysis of the use of language spoken by the main character in the film I Leave My Heart in Lebanon, with the stages: 1) Organizing the data by collects of all the data in the movie that contains of deixis. 2) Categorizing the data into the types based on levinson theory who classified deixis into deixis persona, spatial, temporal, discourse, and social. 3) Analyzing the data which containing five types of deixis. 4) Present the sample of the data that related to the study, the researcher will present the result of the research some of each. All of the sources taken on the Film I Leave My Heart in Lebanon.

\section{RESULTS AND DISCUSSION}

\section{Results}

Levinson (1983) in Abdullah (2015) classified the type of deixis become five types, that is person, spatial, temporal, social, and discourse deixis. Below is the kind of deixis spoken by the actor name "Satria" in the film I Leave My Heart in Lebanon

Table 1. Deixis Used by the Main Character on the Film I Leave My heart in Lebanon

\begin{tabular}{ccc}
\hline Type of Dexis & Number of Words & Percentage \\
\hline Person & 102 & $82 \%$ \\
Spatial & 11 & $9 \%$ \\
Temporal & 8 & $6 \%$ \\
Social & 1 & $1 \%$ \\
Discourse & 3 & $2 \%$ \\
\hline Total & 125 & 66 \\
\hline
\end{tabular}

Table 1 show the number of deixis voiced by Satria. From the table above, it can be see that the main character named Satria mostly used person deixis with the frequency of 102 $(82 \%)$. Then, the main character also apply spatial deixis with a number $11(9 \%)$. The next deixis used by Satria is temporal deixis that appears $8(6 \%)$. Beside that, Satria utilize social deixis that appears with the frequency of $1(1 \%)$. The Last deixis that appears is discourse deixis with the frequency of $3(2 \%)$.

Table 2. Person Deixis in the Main Character on the film Titled I Leave My Heart in Lebanon

\begin{tabular}{cc}
\hline Types of Person Deixis & Number of Words \\
\hline I (Aku) & 24 \\
I (Saya) & 25 \\
You (Kamu) & 33 \\
He (Dia) & 2
\end{tabular}




\begin{tabular}{cc} 
We $($ Kita $)$ & 9 \\
We $($ Kami $)$ & 7 \\
Call name & 2 \\
\hline Total & $\mathbf{1 0 2}$ \\
\hline
\end{tabular}

Table 3. Spatial Deixis in the Main Character on the film Titled I Leave My Heart in Lebanon

\begin{tabular}{cc}
\hline Types of Spatial Deixis & Number of Words \\
\hline Here & 10 \\
There & 1 \\
\hline Total & $\mathbf{1 1}$ \\
\hline
\end{tabular}

Table 4. Temporal deixis in the main character on the film titled I Leave My Heart in Lebanon

\begin{tabular}{cc}
\hline Types of Temporal Deixis & Number of Words \\
\hline Later & 4 \\
Tomorrow & 1 \\
Today & 2 \\
Year & 1 \\
\hline Total & $\mathbf{8}$ \\
\hline
\end{tabular}

Table 5. Social Deixis in the Main Character on the film titled I Leave My Heart in Lebanon

\begin{tabular}{cc}
\hline Types of Social Deixis & Number of Words \\
\hline Excuse me Commandant & 1 \\
\hline Total & 1 \\
\hline
\end{tabular}

Table 6. Discourse Deixis in the Main Character on the film Titled I Leave My Heart in Lebanon

\begin{tabular}{cc}
\hline Types of Discourse Deixis & Number of Words \\
\hline This & 2 \\
That & 1 \\
\hline Total & $\mathbf{3}$ \\
\hline
\end{tabular}

\section{Discussion}

Refers to the result above, it can be see that in the film titled I Leave My Heart in Lebanon found the type of deixis. Table 1 show the result about all the type of deixis that uttered by Satria as the main character on the film I leave My Heart in Lebanon. whereas the Table 2 reveal the type of personal deixis spoken by Satria which involve the use of pronoun, as: I (aku), I (saya), you (kamu), he (dia), we (kami), we (kita) and call name. The number of each data can 
be seen on the table above. In this case, dominated by pronoun "you" (33). The example as follows:

1. I $(a k u)$ hope you will understand that one.

2. We (kami) are fine, sir.

3. I (saya) know this is hard to you.

4. Is this the last time we (kita) met?

5. you are amazing

6. Is he loving you?.

7. where is salma.

The first example (data 1) pronoun I means "aku" because satria doing conversation with the person who have the same status (impolite), whereas pronoun I (data 3) means "saya" because Satria doing conversation on the situation who requires to speak polite. On data 2, pronoun we mean "kami", because in that film, Satria doing conversation with his father and tell about the condition between Satria and Diah are still fine. Whereas pronoun we on the data 4 mean "kita". Because in that film, satria did the conversation with Diah (satria's girlfriend) and ask to Diah "Is this the last time we (kita) met?". On the five data (data 5) pronoun you refers to Lebanon army. In data (6), pronoun he refers to Isni boyfriend. And the last data (data 7) Satria point someone with call the name directly, that is with call "salma" to Rania's son.

Second type is about spatial deixis (see Table 3) which display the various kind of spatial deixis used by Satria. Table 3 shows that there are two type of spatial deixis that found in the main character on the film I Leave My Heart in Lebanon. Satria used the word "here" and "there" to express spatial deixis that indicate the specific location when the conversation happen. For instance: 1. "Wait me here when I come back later." And 2."For all, we don't know what happened there". Those example refers to the particular place when the dialogue happen. The first example (data 1) show that the word "Here" refers to the place in Airport, whereas on the second data (data 2) the word "there" refers to the specific place that is the war situation in Lebanon.

Third, investigate about temporal deixis (see Table 4). Table 4 reveal that there are some of the type of temporal deixis which spoken by the main character named Satria, that is later, tomorrow, today and year. The example as follow: 1. "We will continue later ". 2. "See you on tomorrow". 3. Isn't today the birthday of the Lebanese army?". 4. "About one year I am here". In here, all of the data $(1,2,3,4)$ indicate that the word "later, tomorrow, today and year" refers to the specific time in conversation spoken by Satria. As the example on the first data, the word "later" refers to specific time for continuing the conversation between Satria and Diah.

The next review about social deixis uttered by Satria. Refers to definition from levinson (1983), social deixis is a statement used to state social relations with reference to social status or the role of participants in conversation such as Sir, My Majesty etc. In the Table 5 can be known that the main character only state the word "Excuse me Commandant" on the sentence "Excuse Commandant, isn't our presence here to provide help to residents here?". The sentence indicates that the type of deixis is social deixis. It can be seen when the actor named satria said 
"Excuse Commandant". That sentence indicates "Honorific" (the interlocutor has a higher social status). The final type of deixis is discourse deixis (see Table 6). On the table 6 we can summarize that the main character utilize the word "This" and "That" to point something. The researcher found the type of discourse deixis in the conversation spoken by Satria. The example as follow: "This toy for you" and "I hope you understand that one". Those example pointed out to exact thing or case which is already known by both parties.

\section{CONCLUSION}

In the main character of the film titled I Leave My Heart in Lebanon, the researcher found the kind of deixis based on levinson theory who classified deixis into personal, spatial, temporal, social and discourse deixis. The researcher found 125 data related to the type of deixis. The deixis in this film are dominated by personal deixis, because the main character more often use pronoun I (aku) 24 data, I (saya) 25 data, we (kami) 7 data, we (kita) 9 data, he (2) data, you (33) data, and pointing via name (2) data. In that film, the actors using the word "here" and "there" to pointed the place (spatial deixis), then using the word "later", "tomorrow", "year" and "today" to pointed the time (temporal deixis). Moreover, the main character used the word "Excuse me" to pointed someone who have the higher status (social deixis). Then, the main character also uses the word "that" or "this" to point the thing (discourse deixis).

\section{ACKNOWLEDGMENTS}

The researcher would like to express my deepest gratitude to Allah SWT. The most beneficent for his mercy and blessing who has given her strength, patience, and courage in her whole life to completed this project as one of requirement to finished study at IKIP SILIWANGI.

This project has been completed because there are a lot of people who made a lot of contribution to it. Therefore the writer would like to extend her deepest gratitude to them, especially to Mrs. Aseptiana Parmawati, M.Pd as the first supervisor who has kindly given invaluable guidance, suggestion, advice, and support in completing this project.

\section{REFERENCES}

Abidin, T. N. (2019). Analysis Of Deixis In The Spongebob Squarepants Movie: A Pragmatic Approach (Doctoral Dissertation, Iain Salatiga).

Abdullah, M. (2015). Deixis: A Pragmatics Analysis. Language In India, 15(12), 3-9.

Ainiyah, K., Sili, S., \& Ariani, S. (2019). Analysis Of Deixis In Pitch Perfect 2 Movie. Jurnal Ilmu Budaya Vol, 3(3).

Indah, O. D., Crestiani, J., \& Ramadhana, M. A. (2018). Nonverbal Communication Used By Students Of Informatics Study Program In Studying English Through Lesson Study. Jurnal Studi Guru Dan Pembelajaran, 1(1), 42-48.

Levinson, Stephen C. 1983. Pragmatics. Cambridge. England: Cambridge Universty Press.

Nadar F.X. 2009. Pragmatik Dan Penelitian Pragmatic. Yogyakarta: Graha Ilmu.

Pangaribuan, R. E., Manik, S., \& Pasaribu, T. (2014). Deixis Used In Business Brochures Text A Pragmatics Study. Majalah Ilmiah Methoda, 4(3), 1-12.

Putri, K. P., \& Angga Maulana, S. S. (2019). An Analysis Of English Language Ability Of Employees At Saung Angklung Udjo Bandung. Kania Perdani Putri: 157010032 (Doctoral 
Dissertation, Sastra Inggris).

Syukur, D. M. (2018). Descriptive Analysis Of Discourse Deixis Used In Politics Column On Jakarta Post In April 2017 (Doctoral Dissertation, Iain Salatiga). 